Cardiology and Angiology: An International Journal
4(4): 147-155, 2015, Article no.CA.2015.038
ISSN: 2347-520X, NLM ID: 101658392
SCIENCEDOMAIN international
WwW.SCiencedomain.org

\title{
Statin Therapy in Patients with Type 2 Diabetes
} Mellitus in Hungary

\author{
Laszlo Mark ${ }^{1^{\star}}$, Istvan Reiber ${ }^{2}$, György Paragh $^{3}$, Istvan Karadi ${ }^{4}$, Gyula Pados ${ }^{5}$, \\ Zoltan Kiss ${ }^{6}$ and György Jermendy ${ }^{7}$ \\ ${ }^{1} 2^{\text {nd }}$ Department of Medicine - Cardiology, Pandy Kalman Bekes County Hospital, Gyula, Hungary. \\ ${ }^{2} 4^{\text {th }}$ Department of Medicine, St. George Fejer County Hospital, Szekesfehervar, Hungary. \\ ${ }^{3} 1^{\text {st }}$ Department of Medicine, Medical and Health Science Centre, University of Debrecen, Debrecen, \\ Hungary. \\ ${ }^{4} 3^{\text {rd }}$ Department of Medicine, Semmelweis University, Budapest, Hungary. \\ ${ }^{5}$ Independent Department of Lipidology, St. Imre Hospital, Budapest, Hungary. \\ ${ }^{6}$ MULTI-GAP Research Group, Budapest, Hungary. \\ ${ }^{7} 3^{\text {rd }}$ Teaching Department of Medicine, Bajcsy-Zsilinszky Hospital, Budapest,
}

Hungary.

Authors' contributions

This work was carried out in collaboration between all authors. Authors LM, IR, GP, IK, Gyula Pados and GJ designed the study, wrote the protocol and completed analysis. Author ZK completed the data entry and managed the statistical analyses of the study. Authors $L M$ and GJ wrote the first draft of the manuscript and managed the literature searches. All authors read and approved the final manuscript.

Article Information

DOI: $10.9734 / C A / 2015 / 22424$ Editor(s):

(1) Wilbert S. Aronow, University of California, College of Medicine, Irvine, USA.

Reviewers:

(1) Mohmed Ashmaig, Children's Hospital Oakland Research Institute, USA.

(2) Mario Bernardo-Filho, Universidade do Estado do Rio de janeiro, Brazil.

Complete Peer review History: http://sciencedomain.org/review-history/12196

Original Research Article

Received $1^{\text {st }}$ October 2015

Accepted $20^{\text {th }}$ October 2015

Published $9^{\text {th }}$ November 2015

\section{ABSTRACT}

Aim: The benefit of statin administration in the secondary prevention of cardiovascular diseases in type 2 diabetes mellitus (T2DM) is well documented. The aim of the study was to evaluate the characteristics of lipid lowering therapy and the attainment of target values.

Study Design: Retrospective data analysis.

Place and Duration of Study: Between 2009 and 2011, Hungary.

Methodology: The study was conducted on the patients with T2DM and established cardiovascular events of general practitioners and specialists from the MULTI GAP (MULTI Goal Attainment 
Problem) survey in Hungary using standardized, structured questionnaires. Data collection was performed in 2009 (1582 patients, 55.0\% men), in 2010 (1159 patients, 58.4\% men) and in 2011 (668 patients, $59.1 \%$ men).

Results: In this study all patients received statins, the most frequently used was atorvastatin, followed in 2009 by simvastatin and 2011 by rosuvastatin. Fibrates were taken by $9.3-11.3 \%$ of patients and ezetimibe by $8.0-15.9 \%$ of patients. The total cholesterol (TC) values in 2009 , in 2010 and in 2011 were $5.27 \pm 1.23 \mathrm{mmol} / \mathrm{l}, 4.90 \pm 1.30 \mathrm{mmol} / \mathrm{l}, 4.88 \pm 1.29 \mathrm{mmol} / \mathrm{l}$, respectively $(\mathrm{p}>0.05)$. The LDL-cholesterol (LDL-C) values were $2.94 \pm 1.04 \mathrm{mmol} / \mathrm{l}, 2.73 \pm 0.95 \mathrm{mmol} / \mathrm{l}, 2.69 \pm 1.03 \mathrm{mmol} / \mathrm{l}$, respectively $(p>0.05)$. The proportion of patients at LDL-C target value of $<2.5 \mathrm{mmol} / \mathrm{l}$ was $35.2 \%$, $42.8 \%, 47.8 \%$ ( $p<0.001$ vs values in 2009 ) while that of $<1.8 \mathrm{mmol} / \mathrm{l}$ was $10.6 \%, 15.9 \%$ and $16.8 \%$, respectively $(p<0.001$ vs values in 2009). There was a linear correlation between the patient compliance estimated by the physicians and the LDL-C achievement rate.

Conclusions: In 2009-2011, a slight improvement in serum cholesterol levels and a significant increase of patients at target TC or LDL-C values were documented among patients with T2DM and cardiovascular diseases. Nevertheless, the authors find very important to improve the quality of lipid lowering treatment in order to increase the number of patients achieving their target lipid values.

Keywords: Type 2 diabetes mellitus; cardiovascular risk factor; serum lipids; serum cholesterol; lipidlowering treatment; statins.

\section{INTRODUCTION}

Cardiovascular disease is a chronic macroangiopathic complication of type 2 diabetes [1]. The mortality statistics derived from several cross-sectional studies, follow-up surveys and population observation studies of patients with type 2 diabetes mellitus (T2DM) have shown that cardiovascular conditions, mainly myocardial infarction and ischemic stroke, are the leading causes of mortality. Lipid disorders play an important role in the fact that cardiovascular diseases are the most frequent chronic complications in T2DM. As a result, the primary and secondary prevention of cardiovascular events has recently become a significant public health challenge in T2DM [2].

The importance of the secondary prevention of cardiovascular diseases in diabetes is supported by a serie of studies $[2,3,4,5,6,7]$. It is well documented that in T2DM the occurrence of myocardial infarction is more frequent, mortality in the acute period is higher, and post-infarction late cardiac complications are more common than in patients with a healthy glucose metabolism. It has been shown that in postmyocardial infarction diabetic patients, the occurrence of congestive heart failure related to left ventricle dysfunction (in severe cases cardiogenic shock) and reinfarction rates are higher, and the five year survival rate is lower than in non-diabetics $[2,3,4,6]$.

Haffner et al. [8] in their follow-up study demonstrated that in post-myocardial infarction diabetics the reinfarction rate is approximately twice (45\%) that of post-MI non-diabetics $(18.8 \%)$ or those diabetics who have not previously suffered a heart attack $(20.2 \%)$. In the OASIS multicenter study, patients with non-Qmyocardial infarction or unstable angina requiring hospitalization were followed for up to two years. In a randomized sample of 8,013 patients, 1,718 $(21 \%)$ suffered from T2DM. In this group the rate of deaths within hospital was $2.9 \%$ and the occurrence of congestive heart failure 12\%; in non-diabetics the rates were $2 \%$ and $8 \%$, respectively [9]. In T2DM, apart from coronary events, carotid and peripheral arterial disease also have major clinical significance as well. It is the nature of the disease that if atherosclerosis is present in one area, it may be assumed that other areas are also involved.

In T2DM the importance of secondary prevention of cardiovascular diseases is clear. This consists of lifestyle modification and pharmacological therapy. In the latter, lipid lowering treatment is of increasing importance [2]. This involves the lowering of LDL-cholesterol (LDL-C) despite the fact that in T2DM the typical dyslipidaemia is an increase in triglycerides and rate of small dense LDL and a decrease in HDL-cholesterol (HDL-C). The drugs of first choice are statins both in nondiabetics and diabetics. In this study the LDL-C and total cholesterol (TC) goals are those recommended by the 4th Hungarian Cardiovascular Consensus Conference [10]. In high-risk patients (such as those with T2DM) the levels are $2.5 \mathrm{mmol} / \mathrm{l}$ and $4.5 \mathrm{mmol} / \mathrm{l}$, respectively; in very high-risk cases (including patients with T2DM and coronary artery disease) the levels are $1.8 \mathrm{mmol} / \mathrm{l}$ and $3.5 \mathrm{mmol} / \mathrm{l}$, respectively [10]. 
Using data from the diabetic patient subgroup of the Hungarian Multi-Goal Attainment Problem (MULTI-GAP) 2009, 2010, and 2011 studies $[11,12,13]$, this paper aims to analyse the characteristics of lipid lowering, the data on the trend of LDL-C levels and the attainment of LDLC goals.

\section{METHODS}

In this study, we analysed the Hungarian MULTIGAP 2009, 2010, and 2011 survey data collected from patients with T2DM, using structured questionnaires to monitor the effectiveness of lipid lowering therapy among high-risk patients of general practitioners (GPs) and specialists. Further details on the methods and the results of these studies are provided elsewhere $[10,11,12,13,14]$. During the study, the principles of the Declaration of Helsinki were observed. The research was approved by the Scientific and Research Ethics Board of the Hungarian Ministry of Health and the patients gave their consent to participate.

Risk classification was performed according to the recommendations of the 4th Hungarian Cardiovascular Consensus Conference: patients with T2DM are categorized as high-risk, while diabetic patients with a history of acute coronary syndrome or other vascular event are categorized as very high-risk patients. In the MULTI GAP studies each patient has a documented history of a cardiovascular event and are thus within the very high-risk category [10].

The number of specialists (internists, diabetologists, cardiologists, neurologists) involved varied between 129 and 149, and that of GPs between 53 and 106. The participating doctors were asked to collect the data of the last 10 patients to have suffered from acute coronary syndrome, stroke, transient ischaemic attack (TIA), and/or peripheral arterial disease.

We registered the patients' gender, age, anthropometric parameters, the presence of diabetes and hypertension, smoking habits and certain laboratory parameters $\left(\mathrm{HbA}_{1 \mathrm{c}}\right.$, fasting and postprandial glucose level, lipid levels), and the patients were asked about their medical cardiovascular prevention treatment. The results of this study were obtained in the same way as those of all MULTI GAP survey $[11,12,13,14]$. In terms of antidiabetic therapy, the diabetics were asked only about the main groups of drugs (alpha-glucosidase inhibitors, sulphonylurea derivatives, biguanides [metformin], thiazolidinediones, insulin, DPP-4-inhibitors). The laboratory data were analysed locally in accredited laboratories. The patients' LDL-C, total cholesterol, HDL-C, and TG levels were available for analysis, the measurements of one patient were made in the same local lab. LDL-C values were accepted regardless of whether they were measured directly or calculated using the Friedewald formula [15], except in cases where the triglyceride levels were above $4.5 \mathrm{mmol} / \mathrm{L}$ $(400 \mathrm{mg} / \mathrm{dL})$ when only direct measurements were accepted. We also analysed the data of T2DM patients taking statins: There were 1,582 in 2009, 1,159 in 2010, and 668 in 2011 (the proportion of males was $55.0 \%, 58.4 \%$ and $59.1 \%$, respectively).

Data collection was also undertaken to examine patients' compliance. As we had no opportunity to count the number of tablets taken, this was estimated by doctors and was based on the frequency of statin prescription, the patients' knowledge and questioning of the patients. The analysis of patients' compliance was undertaken by pooling the data for the three years.

\subsection{Statistical Analyses}

Descriptive statistics are presented as frequencies and percentages for categorical variables and as the mean values $\pm S D$ for continuous variables. Categorical variables were compared using the chi-square test. The MannWhitney $U$ test was used for continuous parametric variables. All tests were two-sided, and $p$ values $<0.05$ were considered statistically significant. Statistical analyses were performed using SPSS 7.5.

\section{RESULTS}

The most important clinical parameters of patients across the years 2009, 2010, and 2011 were: Age (years) 64.1 $\pm 9.9,65.4 \pm 9.2$, $66.2 \pm 9.8$; body weight $(\mathrm{kg}) 87.7 \pm 15.7,87.8 \pm 15.7$, 86.6 \pm 16.4 ; Body Mass Index (BMl, $\mathrm{kg} / \mathrm{m}^{2}$ ) $30.2 \pm 5.6,30.6 \pm 5.2,30.6 \pm 5.1$.

Across the three years examined, the TC and LDL-C values decreased continuously $(p>0.05)$. Although the target values recommended for high-risk patients (TC $<4.5 \mathrm{mmol} / \mathrm{l}, \mathrm{LDL}-\mathrm{C}<2.5$ $\mathrm{mmol} / \mathrm{l})$ and for very high-risk patients (TC $<3.5$ $\mathrm{mmol} / \mathrm{l}$, LDL-C $<1.8 \mathrm{mmol} / \mathrm{l}$ ) were attained to a statistically higher degree, these remained lower 
than $50 \%$ concerning the goals for high-risk patients and lower than $20 \%$ for the very highrisk cases. (As the 2TDM patients in the MULTI GAP studies are in the very high-risk category, the unfavourable latter values should mainly be taken into account). A greater improvement in goal attainment was observed between 2009 and 2010, than between 2010 and 2011 (Table 1).

The value of $\mathrm{HbA}_{1 \mathrm{c}}$ was $7.29 \pm 1.09 \%$ in 2009 and $7.23 \pm 1.17 \%$ in 2011 ( $p=0.024)$. The distribution of the $\mathrm{HbA}_{1 \mathrm{c}}$ values is presented in Fig. 1.

Table 1. Serum total cholesterol and LDL-cholesterol and the attainment of target values in patients taking statins with type 2 diabetes mellitus (MULTI GAP 2009, 2010, 2011 studies)

\begin{tabular}{|c|c|c|c|}
\hline & $\begin{array}{l}2009 \\
(n=1582)\end{array}$ & $\begin{array}{l}2010 \\
(n=1159)\end{array}$ & $\begin{array}{l}2011 \\
(n=668)\end{array}$ \\
\hline $\begin{array}{l}\text { Total cholesterol } \\
(\mathrm{mmol} / \mathrm{l})\end{array}$ & $5.27 \pm 1.23$ & $4.90 \pm 1.30$ & $4.88 \pm 1.29$ \\
\hline $\begin{array}{l}\text { LDL-cholesterol } \\
(\mathrm{mmol} / \mathrm{l})\end{array}$ & $2.94 \pm 1.04$ & $2.73 \pm 0.95$ & $2.69 \pm 1.03$ \\
\hline $\begin{array}{l}\text { The attainment rate of total cholesterol } \\
<4.5 \mathrm{mmol} / \mathrm{l}(\%)\end{array}$ & 24.3 & $38.4^{*}$ & $40.4^{*} \dagger$ \\
\hline $\begin{array}{l}\text { The attainment rate of total cholesterol }<3.5 \mathrm{mmol} / \mathrm{l} \\
(\%)\end{array}$ & 6.0 & $11.5^{\star}$ & $12.0^{\star}$ \\
\hline $\begin{array}{l}\text { The attainment rate of LDL-cholesterol } \\
<2.5 \mathrm{mmol} / \mathrm{l}(\%)\end{array}$ & 35.2 & $42.8^{*}$ & $47.8^{\star} \ddagger$ \\
\hline $\begin{array}{l}\text { The attainment rate of LDL-cholesterol } \\
<1.8 \mathrm{mmol} / \mathrm{l}(\%)\end{array}$ & 10.6 & $15.9^{*}$ & $16.8^{\star}$ \\
\hline
\end{tabular}

\section{Patients' \%}

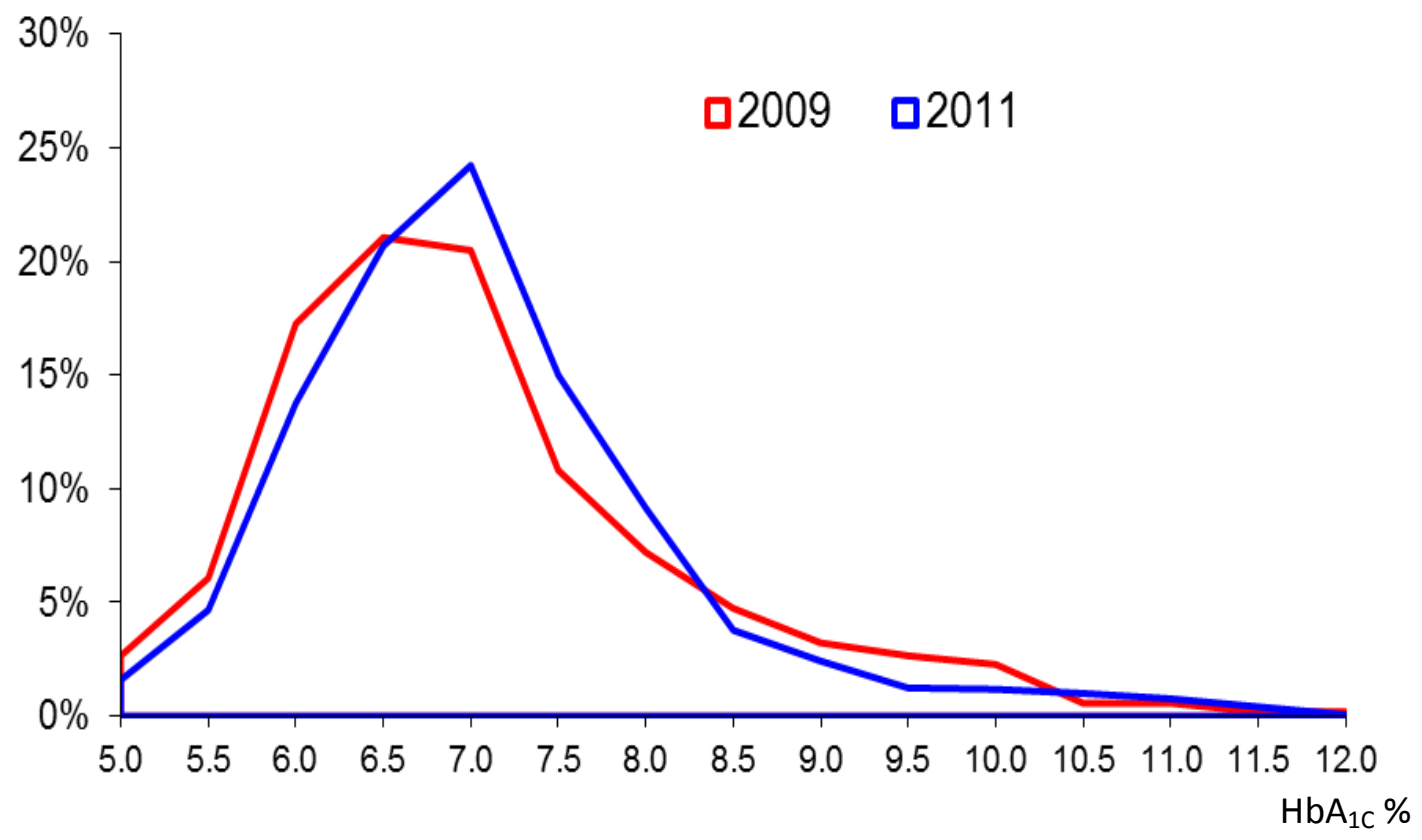

Fig. 1. Distribution of $\mathrm{HbA}_{1 \mathrm{c}}$ values in patients with type 2 diabetes mellitus participating in the MULTI GAP study in the years 2009 and 2011 
There was a linear correlation between the estimated patients' compliance, i.e. their willingness to cooperate in drug taking, and the achievement of $2.5 \mathrm{mmol} / \mathrm{l}$ LDL-C target value (Fig. 2).

The most frequently used statin in 2009 was atorvastatin, followed by simvastatin and rosuvastatin (mean daily doses of $33.8 \mathrm{mg}, 31.0$ $\mathrm{mg}$ and $18.2 \mathrm{mg}$, respectively). By 2011, a remarkable change had occurred: in second place after atorvastatin (mean daily dose 32.9 $\mathrm{mg}$ ) was rosuvastatin (mean daily dose $19.5 \mathrm{mg}$ ), followed by simvastatin (mean daily dose 19.8 $\mathrm{mg}$ ). Fibrates were taken by $9.3-11.3 \%$ of patients and ezetimibe by $8.0-15.9 \%$ of patients (Fig. 3).

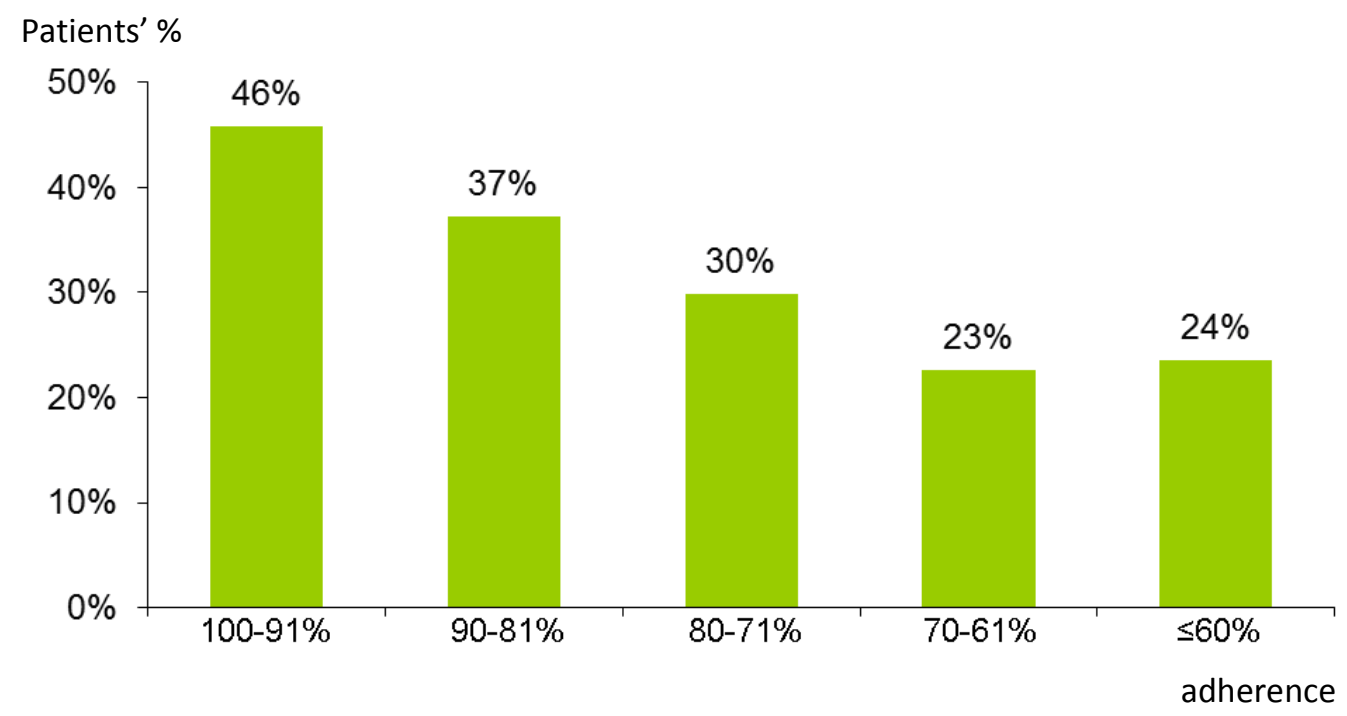

Fig. 2. Correlation between estimated patients' compliance and goal attainment rate (pooled analysis for three years)

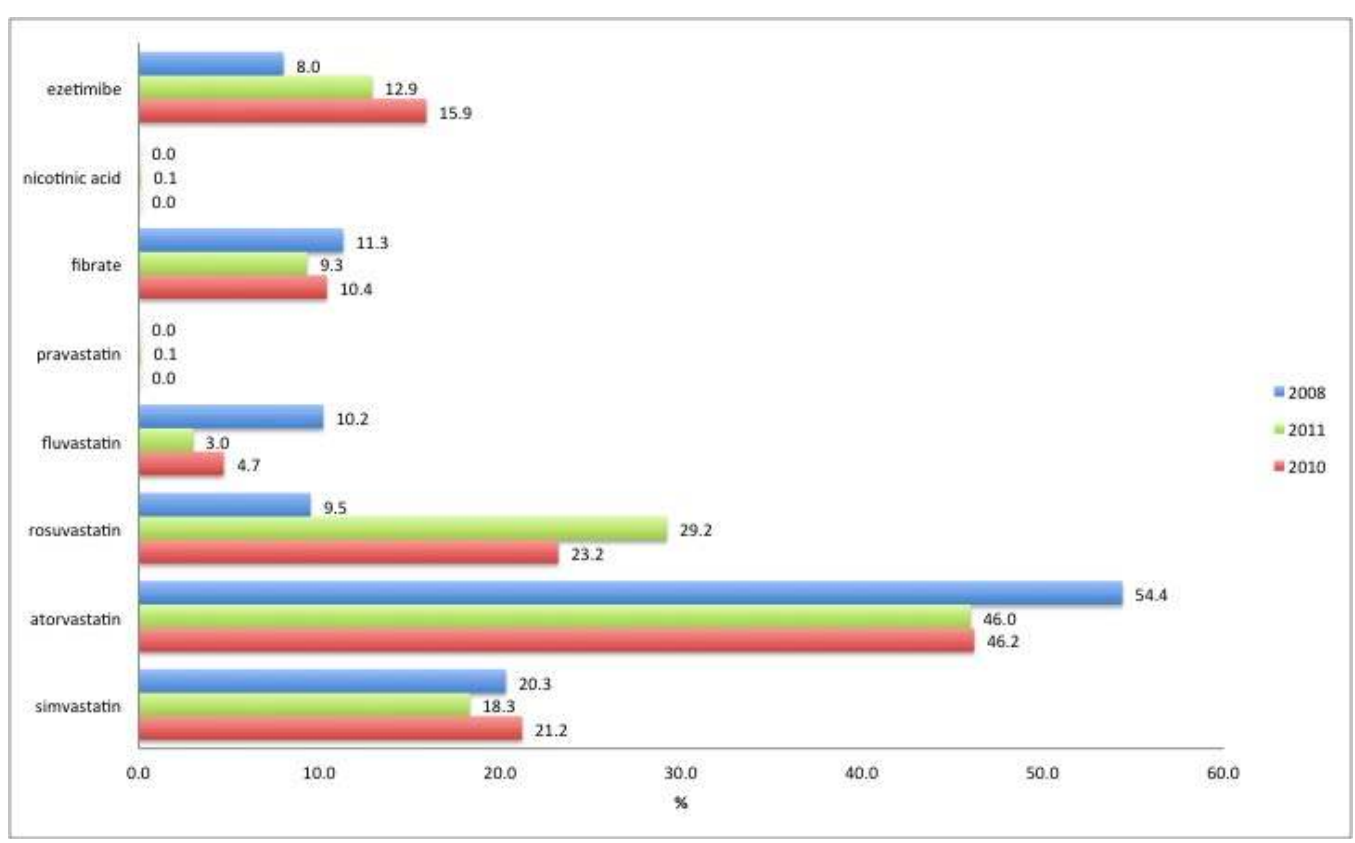

Fig. 3. The distribution of lipid lowering therapy in patients with type 2 diabetes mellitus in 2009, 2010, and 2011 


\section{DISCUSSION}

In the prevention of cardiovascular disease in patients with T2DM, the attainment of the LDL-C target value assessed by guidelines is of very great importance. Triglyceride and HDL-C levels are also relevant, but their values as treatment goals are less significant. Recently, the level of non-high-density lipoprotein cholesterol (nonHDL-C) has been defined as an additional treatment target, secondary to LDL-C, especially in conditions associated with high triglyceride levels such as T2DM. Nevertheless, the use of non-HDL-C has not yet become part of routine practice $[16,17]$.

As for the treatment goals, we have taken into consideration the recommendations of the $4^{\text {th }}$ Hungarian Cardiovascular Consensus Conference [10], which are similar to and based on those of the National Cholesterol Education Program Adult Treatment Panel III (NCEP ATP III), and the joint recommendations for the treatment of dyslipidemias by the European Society of Cardiology, the European Atherosclerosis Society (ESC/EAS) and the International Society of Atherosclerosis $[18,19,20]$.

The priority of statin therapy in T2DM patients is indisputable [2,21] As the LDL-C and TC values are high in most diabetics, the use of statins is indispensable. In T2DM cases, doctors do not have to explain why they administer statins, rather they should explain why they do not. In this study all patients received statins. We analysed separately the attainment rate of lipid goals for high-risk patients (TC $<4.5 \mathrm{mmol} / \mathrm{l}$, LDL$\mathrm{C}<2.5 \mathrm{mmol} / \mathrm{l}$ ) and for very high-risk patients (TC $<3.5 \mathrm{mmol} / \mathrm{l}$, LDL-C $<1.8 \mathrm{mmol} / \mathrm{l})$. The less strict high-risk lipid goals are recommended for patients with atherosclerotic disease (coronary, carotid or peripheral) or patients with T2DM. In this study, all patients were in the very highrisk category as, besides having T2DM, an atherosclerotic event had also occurred (this was an inclusion criterion). Between 2009 and 2011 a decreasing tendency could be observed in LDL$C$ and TC levels and the rate of patients achieving lipid goals increased. However, despite the improvement in the quality of the treatment, the high-risk lipid goal attainment rate was less than $50 \%$, and that of the very high-risk goals was critically less than $20 \%$. In contrast, glycaemic control was acceptable (mean $\mathrm{HbA}_{1 \mathrm{c}}$ values $7.29-7.23 \%$ ).
What could be the reason for the only modest improvement derived from the statin therapy? This is not specific to diabetes but is common in other MULTI GAP analyses [11,12,13,14]. In most cases three statins were administered, the effectiveness of which is supported by a series of studies. In the period analysed, use of the most potent statin, rosuvastatin, became more frequent. In relation to increasing doses, we ascertained that only a slight improvement could be obtained by this means. It is well known that by doubling the statin dose an additional $5-7 \%$ lowering of LDL-C could be expected [22]. The ezetimibe proved to be an efficient drug not only $\mathrm{n}$ lowering LDL-C but in the reduction of the clinical events too [23]. Its more frequent use of would be another possible source of further improvement [24,25].

The most important reason for the failure to derive better results from treatment could be patients' compliance. Our data suggest that greater willingness to cooperate can significantly improve the goal attainment rate. Recently we have shown that persistence in taking statins in Hungarian patients is very poor: At 12 months only $26.3 \%$ of T2DM patients were taking the statins prescribed [26,27]. To improve the patients' persistence have accentuated importance.

The clear advantages of statin administration in relation to the cardiovascular endpoints and mortality are unquestionable. The potential side effects are also well known and these include the worsening of glycaemic control, an increased rate of new onset diabetes [28,29,30,31,32,33]. However, we agree with the opinion that overall the favourable effects outweigh the harmful effects [21,31]. This is the present standpoint of the U.S. Food and Drug Administration (FDA) [34]. The use of statins in patients with T2DM is a crucial aspect of secondary cardiovascular disease prevention. We suppose that their administration has played an important role in the fact that life expectancy in Hungary increased by 5.33 years from 1993 to 2010, of which 2.39 years were accounted for by a decrease in cardiovascular mortality $[35,36]$ and this occurred despite an increase in the prevalence of some other cardiovascular risk factors such as obesity and T2DM $[37,38]$.

\section{CONCLUSION}

Administration of statins is the crucial part of lipid lowering therapy in patients with T2DM and 
cardiovascular diseases. Between 2009 and 2011 a slight improvement in serum cholesterol levels and a significant increase of patients at target TC or LDL-C values had been detected. Statin use shifted towards the most portent atorvastatin and rosuvastatin. Despite these favourable changes a continuous need remains for more effective lipid lowering treatment in order to increase the rate of patients with target lipid values.

\section{COMPETING INTERESTS}

Authors have declared that no competing interests exist.

\section{REFERENCES}

1. Fowler MJ. Microvascular and macrovascular complications of diabetes. Clinical Diabetes 2008;26:77-82.

DOI: 10.2337/diaclin.26.2.77

2. Rydén L, Grant PJ, Anker SD, Berne C, Cosentino F, Danchin N, et al. ESC guidelines on diabetes, pre-diabetes, and cardiovascular diseases developed in collaboration with the EASD: The task force on diabetes, pre-diabetes, and cardiovascular diseases of the European Society of Cardiology (ESC) and developed in collaboration with the European Association for the Study of Diabetes (EASD). Eur Heart J. 2013; 34(39):3035-87.

3. Eckel RH, Barouch WW, Ershow AG. Report of the National Heart, Lung, and Blood Institute-National Institute of Diabetes and Digestive and Kidney Diseases Working Group on the pathophysiology of obesity-associated cardiovascular disease. Circulation. 2002; 105:2923-8.

4. Ray KK, Seshasai SR, Wijesuriya S, et al. Effect of intensive control of glucose on cardiovascular outcomes and death in patients with diabetes mellitus: A metaanalysis of randomised controlled trials. Lancet. 2009;373(9677):1765-72.

5. Sarwar N, Gao P, Seshasai SR, et al. Emerging risk factors collaboration. Diabetes mellitus, fasting blood glucose concentration, and risk of vascular disease: A collaborative meta-analysis of 102 prospective studies. Lancet, 2010;375: 2215-2222.

6. Bays HE. Lowering low-density lipoprotein cholesterol levels in patients with type 2 diabetes mellitus. Int J Gen Med. 2014;7: 355-364.

7. Bolli P. Treatment of dyslipidemia: The problem of reaching the goal. Atherosclerosis. 2014;236:142-143.

8. Haffner SM, Lehto $S$, Rönnemaa $T$. Pyörälä K, Laakso M. Mortality from coronary heart disease in subjects with type 2 diabetes and in nondiabetic subjects with and without prior myocardial infarction. N Engl J Med. 1998;339:229-34.

9. Malmberg K, Yusuf $S$, Gernstein HC, Brown J, Zhao F, Hunt D, et al. For the OASIS registry investigators: Impact of diabetes on long-term prognosis in patients with unstable angina and non-Q-wave myocardial infarction: Results of OASIS (Organization to Assess Strategies for Ischemic Syndromes) Registry. Circulation. 2000;102:1014-1019.

10. $\mathrm{Az} \quad \mathrm{V}$. Magyar Kardiovaszkuláris Konszenzus Konferencia (The V. Hungarian Cardiovascular Consensus Conference). Metabolizmus. 2012; 10 Suppl A:A4-A79. (Hungarian)

11. Mark L. Paragh Gy, Karadi I, Reiber I, Pados Gy. Changes in attainment of lipid goals by general practitioners and specialists in patients at high cardiovascular risk in Hungary during 2004-2008. Arch Med Sci. 2010;6:695700.

12. Mark L, Paragh Gy, Karadi I, Reiber I, Pados Gy. Kiss Z. An attempt to make the lipid lowering therapy more effective in Hungary. The results of MULTI GAP 2010 and Plus Program. Arch Med Sci. 2011; 7:760-6.

13. Mark L, Paragh Gy, Karadi I, Reiber I, Pados GY, Kiss Z. How can we further improve the LDL-cholesterol target level achievement rate based on the Hungarian MULTI GAP 2011 study results and considering the new European dyslipidaemia guidelines? Arch Med Sci. 2012;8:608-13.

14. Mark L, Vallejo-Vaz AJ, Reiber I, Paragh Gy, Seshasai SRK, Ray KK. Non-HDL cholesterol goal attainment and its relationship with triglyceride concentrations among diabetic subjects with cardiovascular disease: A nationwide survey of 2,674 individuals in Hungary. Atherosclerosis. 2015;241:62-68.

15. Friedewald WT, Levy RI, Fredrickson DS. Estimation of the concentration of low- 
density lipoprotein cholesterol in plasma, without use of the preparative ultracentrifuge. Clin Chem. 1972;18:499502.

16. Boekholdt SM, Arsenault BJ, Mora S, Pedersen TR, LaRosa JC, Nestel PJ, et al. Association of LDL cholesterol, non-HDL cholesterol, and apolipoprotein B levels with risk of cardiovascular events among patients treated with statins: A metaanalysis. JAMA. 2012;307:1302-9.

17. Reiber I, Mező I, Mark L, Paragh Gy. The good, the bad, and the atherogenic. Letter to the Editor. J Am Coll Cardiol. 2012; 59:1333-4.

18. National Cholesterol Education Program (NCEP) expert panel on detection, evaluation, and treatment of high blood cholesterol in adults (Adult Treatment Panel III). Third Report of the National Cholesterol Education Program (NCEP) Expert Panel on Detection, Evaluation, and Treatment of High Blood Cholesterol in Adults (Adult Treatment Panel III) final report. Circulation. 2002;106:3143-3421.

19. Reiner Z, Catapano AL, De Backer G, Graham I, Taskinen MR, Wiklund O, et al. The task force for the management of dyslipidaemias of the European Society of Cardiology (ESC) and the European Atherosclerosis Society (EAS). ESC/EAS guidelines for the management of dyslipidaemias. Eur Heart J. 2011;32: 1769-1818.

20. An International Atherosclerosis Society Position Paper. Global recommendations for the management of dyslipidemia. Available:http://www.athero.org/IASPositio nPaper.asp

21. Kearney PM, Blackwell L, Collins R, Keech A, Simes J, Peto R, et al. Cholesterol Treatment Trialists' (CTT) collaborators. Efficacy of cholesterol-lowering therapy in 18,686 people with diabetes in 14 randomised trials of statins: A metaanalysis. Lancet. 2008;371:117-25.

22. Illingworth DR. Management of hypercholesterolemia. Med Clin North Am. 2000;84:23-42.

23. Cannon $\mathrm{CP}$, Blazing MA, Giugliano RP, McCagg A, White JA, Theroux $P$, et al. IMPROVE-IT Investigators. Ezetimibe added to statin therapy after acute coronary syndromes. N Engl J Med. 2015; 372(25):2387-2397.
24. Mark L, Reiber I, Bajnok L, Karadi I, Paragh $G$. The effect of switching to the high-efficient rosuvastatin on the success of lipid lowering therapy in high risk patients. The CORVUS (Controlled Targets for High Vascular Risk Patients Using Effective Statins) study. Pharm Anal Acta. 2012;S10:001.

DOI: 10.4172/2153-2435.S10-001

25. Mark L, Paragh Gy, Reiber I. The role of ezetimibe in LDL cholesterol goal attainment in very high risk patients. The rosuvastatin monotherapy looks to be insufficient. Letter to the Editor. Curr Med Res Opin. 2011;27:1959-60.

26. Kiss Z, Nagy L, Reiber I, Paragh Gy, Molnar MP, Rokszin Gy, Abonyi-Toth ZS, Mark L. Persistence with statin therapy in Hungary. Arch Med Sci. 2013;9:409-17.

27. Jermendy G, Wittmann I, Nagy L, Kiss Z, Rokszin G, Abonyi-Tóth Z, Katona L, Paragh G, Karádi I, Merkely B. Persistence of initial oral antidiabetic treatment in patients with type 2 diabetes mellitus. Med Sci Monit. 2012;18:CR72-77.

28. Sattar N, Preiss D, Murray HM, Welsh P, Buckley BM, de Craen AJ, et al. Statins and risk of incident diabetes: $A$ collaborative meta-analysis of randomised statin trials. Lancet. 2010;375:735-742.

29. Rajpathak SN, Kumbhani DJ, Crandall J, Barzilai N, Alderman M, Ridker PM. Statin therapy and risk of developing type 2 diabetes: A meta-analysis. Diabetes Care 2009;32:1924-1929.

30. Culver AL, Ockene IS, Balasubramanian R, Olendzki BC, Sepavich DM, WactawskiWende J, et al. Statin use and risk of diabetes mellitus in postmenopausal women in the Women's Health Initiative. Arch Intern Med. 2012;172:144-152.

31. Preiss D, Seshasai SR, Welsh P, Murphy SA, Ho JE, Waters DD, et al. Risk of incident diabetes with intensive-dose compared with moderate-dose statin therapy: A meta-analysis. JAMA. 2011;305: 2556-64.

32. van de Woestijne AP, van der Graaf $Y$, Westerink J, et al. Effect of statin therapy on incident type 2 diabetes mellitus in patients with clinically manifest vascular disease. Am J Cardiol. 2015;115:441-6.

33. Muscogiuri G, Sarno G, Gastaldelli A, et al. The good and bad effects of statins on insulin sensitivity and secretion. Endocr Res. 2014;39:137-43. 
34. FDA Drug Safety Communication. Important safety label changes to cholesterol-lowering statin drugs (2012. 02. 28).

Available:http://www.fda.gov/Drugs/DrugS afety/ucm293101.htm

35. Jozan P. (Change of the political system and epidemiologic transition in Hungary). Rendszerváltozás és epidemiológiai korszakváltás Magyarországon. Orv Hetil. 2012;153:662-77.

36. Balogh $S$, Papp R, Józan $P$, Császár $A$. Continued improvement of cardiovascular mortality in Hungary - Impact of increased cardio-metabolic prescriptions. BMC Public Health. 2010;10:422-429.
37. Kotseva K, Wood D, De Backer G, De Bacquer D, Pyörälä K, Keil U. EUROASPIRE Study Group. EUROASPIRE III: A survey on the lifestyle, risk factors and use of cardioprotective drug therapies in coronary patients from 22 European countries. Eur $\mathrm{J}$ Cardiovasc Prev Rehabil. 2009;16:121-137.

38. Jermendy G, Nádas J, Szigethy E, Széles G, Nagy A, Hídvégi T, et al. Prevalence rate of diabetes mellitus and impaired fasting glycemia in Hungary - Crosssectional study on nationally representative sample of people aged 2069 years. Croat Med J. 2010;51:151-156.

(0) 2015 Mark et al.; This is an Open Access article distributed under the terms of the Creative Commons Attribution License (http://creativecommons.org/licenses/by/4.0), which permits unrestricted use, distribution, and reproduction in any medium, provided the original work is properly cited.

Peer-review history:

The peer review history for this paper can be accessed here: http://sciencedomain.org/review-history/12196 